\title{
IL-33 Aggravates DSS-Induced Acute Colitis in Mouse Colon Lamina Propria by Enhancing Th2 Cell Responses
}

\author{
Junfeng Zhu, ${ }^{1,2}$ Fangli Yang, ${ }^{1}$ Lixuan Sang, ${ }^{1}$ Jingbo Zhai, ${ }^{1}$ Xiaoqing Zhang, ${ }^{1}$ Dan Yue, \\ Shengjun Li, ${ }^{1}$ Yan Li, ${ }^{1}$ Changlong Lu, ${ }^{1}$ and Xun Sun ${ }^{1}$ \\ ${ }^{1}$ Department of Immunology, China Medical University, Shenyang 110122, China \\ ${ }^{2}$ School of Life Science, Liaoning University, Shenyang 110036, China \\ Correspondence should be addressed to Changlong Lu; cllu@mail.cmu.edu.cn
}

Received 1 December 2014; Revised 29 January 2015; Accepted 3 February 2015

Academic Editor: Guanglin Cui

Copyright (C) 2015 Junfeng Zhu et al. This is an open access article distributed under the Creative Commons Attribution License, which permits unrestricted use, distribution, and reproduction in any medium, provided the original work is properly cited.

Interleukin- (IL-) 33, a member of the IL-1 cytokine family, is an important modulator of the immune system associated with several immune-mediated diseases. IL-33 was expressed in high level on epithelial cells of intestinal tract. It suggested that IL-33 plays a potential role in inflammatory bowel diseases (IBD). We investigated the role of interleukin- (IL-) 33 in dextran sulphate sodium(DSS-) induced acute colitis in mice using recombinant mouse IL-33 protein (rIL-33). We found that DSS-induced acute colitis was aggravated by rIL-33 treatment. rIL-33-treated DSS mice showed markedly reduced levels of interferon- (IFN-) $\gamma$ and IL-17A in their colon lamina propria lymphocytes (LPL), but the levels of Th2 cytokines, such as IL-5 and IL-13, in these cells were significantly increased, compared to DSS mice treated with PBS. Our results suggested that IL-33 stimulated CD $4^{+} \mathrm{T}$ cells and caused the cell to adopt a Th2-type response but at the same time suppressed Th17 and Th1 cell responses. Therefore, IL-33 may be involved in pathogenesis of DSS-induced acute colitis by promoting Th2 cell response in intestinal mucosa of mice. Modulation of IL-33/ST2 signaling by monoclonal antibody $(\mathrm{mAb})$ could be a novel biological therapy in DSS-induced acute colitis.

\section{Introduction}

Inflammatory bowel diseases (IBD), including Crohn's disease (CD) and ulcerative colitis (UC), are characterized by inflammation in the large and/or small intestine associated with uncontrolled innate and adaptive immunity against normal constituents, including commensal bacteria and various microbial products $[1,2]$. We used to think that the responding $\mathrm{T}$ cells exhibit a $\mathrm{T}$-helper $(\mathrm{Th})$ cell type 1 phenotype capable of producing IFN- $\gamma$ in $\mathrm{CD}$ [3], whereas Th2 cytokine, such as IL-4, IL-5, or IL-13, is closely associated with UC [4]. In addition to these major immune responses associated with $\mathrm{CD}$ and UC, Th17, which mainly produces IL-17A, has also been linked to pathogenesis of IBD recently $[5,6]$. Among various experimentally induced colitis models in mice, dextran sulphate sodium- (DSS-) induced acute or chronic colitis is the most commonly used as IBD animal models $[7,8]$. In the DSS-induced acute colitis model, mice are treated with DSS polymers in the drinking water and this colitis model is characterized by diarrhea, bloody faeces, weight loss, and a histological picture of inflammation and ulceration as seen in UC $[9,10]$. Although the acute intestinal inflammation can be induced by DSS in the T cellindependent condition [10], the adaptive immune responses mediated by Th2 cell play a needful role in the pathogenesis of DSS-induced acute colitis [11].

Similar to IL-1 and IL-18, IL-33, also known as NF-HEV, is a newly identified cytokine belonging to the IL-1 family that is mainly expressed in endothelial cells of all organs and in epithelial cells of mucosa-associated tissues such as the intestine and airways [12-16]. ST2 is the IL-33 receptor and exists in two different splice variants leading to the synthesis of ST2L, a transmembrane receptor that confers the biologic effects on IL-33 [17, 18], and sST2, a soluble molecule which likely serves as a decoy receptor by interacting with IL-33 and blocking its biological effects $[19,20]$. As recent reports, ST2L is mainly expressed on Th2 cells [12, 21, 22]. Therefore, IL-33/ST2 axis has been shown to play an important role in 
intestinal inflammation associated with a predominant Th2 response.

Although the levels of IL-33 are elevated in human UC $[23,24]$, the role of increased IL-33 production during intestine inflammation remains unclear. There are several lines of evidence showing that IL-33 plays a pathogenic role in acute intestinal inflammation [25-28]. However, a number of recent studies have suggested that IL-33 attenuates the development and perpetuation of chronic intestinal inflammation $[25,29]$. These findings have also been replicated in the trinitrobenzene-sulfonic-acid- (TNBS-) induced colitis model [30]. There are several lines of evidence showing that the IL-33 is associated with the development of Th2 immunity, and it induces the production of Th2-type cytokines [27, 30]. However, little is known about the role of IL-33 in UC. In the present study, we used DSS-induced acute colitis (a representative colitis model for UC) in mice to elucidate the influence of IL-33 in the development of inflammatory condition.

\section{Materials and Method}

2.1. Animals. Seven-week-old male C57BL/6 mice weighing about 18-22 g were purchased from Beijing HFK Bioscience Co., Ltd. (Beijing, China). The mice were maintained under special-pathogen-free conditions at China Medical University for at least 1 week before being used in experiments. All of the studies were performed in accordance with the China Medical University Animal Care and Use Committee guidelines.

2.2. Expression and Purification of rIL-33. Full-length mouse IL-33 was amplified from mouse spleen cDNA and cloned into a pUC-T vetor (Beijing CoWin Biotech, Beijing, China). The insert was confirmed by direct DNA sequencing. The cDNA sequence, starting with amino acid 112 of the fulllength protein, was then amplified from the above plasmid containing the mature IL-33 using specific primer pairs: $5^{\prime}$-GCATGAATTCATGACATTGAGCATCCAAGGAAC-3' (forward) and $5^{\prime}$-CCGCCTCGAGGATTTTCGAGAGCTTAAACA $-3^{\prime}$ (reverse). The resulting amplified fragment was inserted into the expression vector pET21a (+) at the EcoR I and Xho I to yield the construct pET21a-IL-33. This construct was transformed into Escherichia coli strain BL21DE3, and the expression of rIL-33 was induced by isopropyl- $\beta$-dthiogalactoside and purified by using $6 \times$ His-Tagged Protein Purification Kit (Beijing CoWin Biotech, Beijing, China), followed by ToxinEraser Endotoxin Removal Kit (GenScript, Nanjing, China) to remove any endotoxin that might have come from the host cells. The purity of rIL-33 was more than 95\% tested by SDS-PAGE, and the endotoxin levels were less than $1 \mathrm{Eu} / \mathrm{mg}$ of protein using ToxinSensor Chromogenic LAL Endotoxin Assay Kit (GenScript, Nanjing, China).

2.3. Antibodies and Reagents. Antibodies for flow cytometry analysis, $\mathrm{Fc} \gamma$ receptor-blocking $\mathrm{mAb}$ (CD16/32; 2.4G2), antiGr-1 (RB6-8C5), anti-CD4 (RM4-5), anti-CD44 (IM7), antiIL-17A (TC11-18H10.1), and anti-IFN- $\gamma$ (XMG1.2) were purchased from BD Biosciences (San Diego, CA, USA). Purified
anti-CD3 and anti-CD28 were also obtained from BD Biosciences (San Diego, CA, USA). Anti-F4/80 (BM8), anti-B220 (RA3-6B2), anti-TCR $\beta$ (H57-597), anti-CD8 (53-6.7), antiNK1.1 (PK136), anti-TCR $\gamma \delta$ (GL3), and anti-CD25 (PC61) were purchased from Biolegend (San Diego, CA, USA).

2.4. Induction of Acute Colitis Model. To induce acute colitis in mice, the animals were orally administered 2.5\% DSS (MW 36,000-50,000, MP Biomedicals, USA) for 7 days. Mice were treated with rIL-33 (1 $\mu$ g in $100 \mu \mathrm{L} \mathrm{PBS/mouse/day)} \mathrm{or} \mathrm{PBS}$ (100 $\mu \mathrm{L} /$ mouse/day) as control on every day. Body weight and the disease activity index (DAI) were monitored daily. DAI was determined by scoring body weight loss, trait of stool, and occult blood in stool or hematochezia according to the classic scoring system described by Cooper et al. [31]. The scoring process is given as follows: body weight loss ( 0 , none; $1,1 \%-$ $5 \% ; 2,5 \%-10 \% ; 3,10 \%-20 \% ; 4,>20 \%)$, stool consistency ( 0 , normal; 2 , loose stool; 4 , diarrhea), and stool blood ( 0 , negative; 2 , fecal occult blood test positive; 4 , gross bleeding). All the animals were sacrificed at the end of the experiment, and the colon tissue was removed and cleaned and then subjected to cell culture, flow cytometry, quantitative realtime PCR, and histological analyses.

2.5. Histological Assessment of Colitis. The middle part of colon was fixed with $4 \%$ paraformaldehyde, and the fixed tissue was then embedded in paraffin. Five-micrometer tissue sections were sliced and stained with H\&E. Histology was scored as described previously [32]. Histology was scored as follows: epithelium (E): 0, normal morphology; 1, loss of goblet cells; 2 , loss of goblet cells in large areas; 3 , loss of crypts; 4 , loss of crypts in large areas and infiltration (I): 0, no infiltrate; 1 , infiltrate around the crypt basis; 2 , infiltrate reaching the L muscularis mucosae; 3 , extensive infiltration reaching the $\mathrm{L}$ muscularis mucosae and thickening of the mucosa with abundant edema; 4, infiltration of the L submucosa. The total histologic score was given as $\mathrm{E}+\mathrm{I}$.

2.6. Cell Preparation. Lamina propria (LP) cells in the colon were isolated by a modified method described previously [33]. In brief, gut pieces were cut into 2-mm slices and the epithelium was eliminated by stirring, first in PBS containing $3 \mathrm{mM}$ EDTA for $10 \mathrm{~min}$ at $37^{\circ} \mathrm{C}$ (twice) and then in RPMI (Sigma Chemical Co., St. Louis, MO, USA) containing $1 \%$ FBS, $1 \mathrm{mM}$ EGTA, and $1.5 \mathrm{mM} \mathrm{MgCl}_{2}$ for $15 \mathrm{~min}$ (also twice). Gut pieces were collected and stirred in RPMI containing 20\% FBS, $100 \mathrm{U} / \mathrm{mL}$ collagenase (C2139; Sigma-Aldrich Corp., St. Louis, MO, USA), and $5 \mathrm{U} / \mathrm{mL}$ DNase 1 (Sigma-Aldrich Corp) for $90 \mathrm{~min}$ at $37^{\circ} \mathrm{C}$. Halfway through the incubation and at the end of the incubation, the suspension was dissociated by multiple aspirations through a syringe for $2 \mathrm{~min}$. The pellet was purified to LPL on a 45\%/66.6\% discontinuous Percoll (Pharmacia, Uppsala, Sweden) gradient at $600 \times \mathrm{g}$ for $20 \mathrm{~min}$. The number of viable cells was counted by trypan blue staining.

2.7. Enzyme-Linked Immunosorbent Assay (ELISA). To measure spontaneous cytokine production by LPL, LPL were 
TABLE 1: Primer sequences for RT-PCR.

\begin{tabular}{|c|c|c|}
\hline Gene & Forward & Reverse \\
\hline IL-4 & $5^{\prime}$-CATCGGCATTTTGAACGAG-3' & $5^{\prime}$-TTGGAAGCCCTACAGACGAG-3' \\
\hline IL-5 & $5^{\prime}$-AGCACAGTGGTGAAAGAGAC-3' & $5^{\prime}$-TCCAATGCATAGCTGGTGATTT-3' \\
\hline IL-10 & $5^{\prime}$-GGTTGCCAAGCCTTATCGGA-3' & $5^{\prime}$-АCСTGCTCCACTGCCTTGCT-3' \\
\hline IL-13 & $5^{\prime}$-GGAGCTGAGCAACATCACAC-3' & $5^{\prime}$-GGTCCTGTAGATGGCATTGCA-3' \\
\hline IL-17A & $5^{\prime}$-GCTCCAGAAGGCCCTCAGA-3' & 5'-AGCTTTCCCTCCGCATTGA-3' \\
\hline IFN- $\gamma$ & $5^{\prime}$-AAAGACAATCAGGCCATCAG-3' & $5^{\prime}$-TGGGTTGTTGACCTCAAACT-3' \\
\hline Foxp3 & $5^{\prime}$-GGCCCTTCTCCAGGACAGA-3' & 5'-GCTGATCATGGCTGGGTTGT-3' \\
\hline GATA-3 & 5'-ACAGCTCTGGACTCTTCCCA-3' & $5^{\prime}$-GTTCACACACTCCCTGCCTT-3' \\
\hline T-bet & $5^{\prime}$-CCAGGGAACCGCTTATATGT-3' & $5^{\prime}$-CTGGGTCACATTGTTGGAAG-3' \\
\hline ROR- $\gamma \mathrm{t}$ & $5^{\prime}$-CCACTGCATTCCCAGTTTCT-3' & $5^{\prime}$-CGTAGAAGGTCCTCCAGTCG-3' \\
\hline$\beta$-actin & $5^{\prime}$-TTCCAGCGTTCCTTCTTGGGT-3' & $5^{\prime}$-GTTGGCATAGAGGTGTTTACG-3' \\
\hline
\end{tabular}

cultured in 96-well flat-bottom plates without any stimulation for $24 \mathrm{~h}$ at $37^{\circ} \mathrm{C}$ under $5 \% \mathrm{CO}_{2}$. The cells were cultured in $0.2 \mathrm{~mL}$ RPMI 1640 (Wako, Osaka, Japan) containing $10 \%$ FBS (Cell Culture Technologies, Tokyo, Japan). The production of TNF- $\alpha$, IL- 6 , IL-1 $\beta$, IL-23, or IL-12p70 was measured using ELISA kits (R\&D Systems). Isolated LPL were incubated for $48 \mathrm{~h}$ in vitro in 96-well flat-bottom plates (Falcon; BD Biosciences) coated with anti-CD3 $(10 \mu \mathrm{g} / \mathrm{mL})$ and anti-CD28 $(1 \mu \mathrm{g} / \mathrm{mL})$ antibodies. IFN- $\gamma$, IL-17A, IL-4, IL10 , IL-5, and IL-13 secreted into the culture medium were measured with ELISA kits (R\&D Systems) according to the manufacturer's instruction.

2.8. Real-Time Quantitative Polymerase Chain Reaction (RT$P C R)$. Total RNA was extracted from colon of mice using the RNAiso plus (Takara, Dalian, China) according to the manufacturer's instruction. $1 \mu \mathrm{g}$ of total RNA from the colon of each mouse was used for reverse transcription performing using a PrimeScript RT reagent kit with gDNA Eraser (Perfect Real Time, Takara) to generate the first strand cDNA. PCR mixture was prepared using SYBR Premix Ex Taq (Tli RNaseH Plus, Takara) and one of primers listed in Table 1. The amplification program consisted of the following steps: $95^{\circ} \mathrm{C}$ for $30 \mathrm{sec}$, and $40 \mathrm{cycles}$ of $95^{\circ} \mathrm{C}$ for $15 \mathrm{sec}$ and $60^{\circ} \mathrm{C}$ for $34 \mathrm{sec}$ on an ABI PRISM 7500 Sequence Detection System (Applied Biosystems, Foster City, CA). Each gene expression was normalized with $\beta$-actin mRNA content.

2.9. Flow Cytometry. Isolated LPL were incubated with an FcgR-blocking $\mathrm{mAb}$ and stained with $\mathrm{mAbs}$ against mouse Gr-1, F4/80, $\alpha \beta$ TCR, $\gamma \delta$ TCR, NK1.1, CD4, CD44, CD25, and B220. For intracellular cytokine staining, LPL were stimulated with PMA ( $25 \mathrm{ng} / \mathrm{mL}$; Sigma-Aldrich, St. Louis, $\mathrm{MO})$ and ionomycin $(1 \mu \mathrm{g} / \mathrm{mL}$; Sigma-Aldrich) for $5 \mathrm{~h}$ at $37^{\circ} \mathrm{C}$. Brefeldin A $(10 \mu \mathrm{g} / \mathrm{mL}$; Sigma-Aldrich) was added after the first hour of incubation. These cells were harvested, washed, and stained with mAbs against mouse IL-17A or IFN$\gamma$ for $30 \mathrm{~min}$ at $4^{\circ} \mathrm{C}$. The intracellular expression of IL-17A and IFN- $\gamma$ in $\mathrm{CD} 4^{+}$T-LPL was analyzed by flow cytometry using a Cytofix/Cytoperm Kit Plus (BD Biosciences, San Jose, CA) according to the manufacturer's instructions.

2.10. Statistical Analysis. The difference in survival rates was assessed by the log rank test (Mantel-Cox). Differences in parametric data were evaluated by a Student's $t$-test. Statistically significant differences were accepted when $P<0.05$.

\section{Results}

3.1. rIL-33 Aggravates DSS-Induced Acute Intestinal Inflammation in Mice. Compared to PBS-treated DSS mice, rIL33-treated DSS mice showed enhanced development of DSSinduced acute colitis as indicated by weight loss, DAI, survival rate, macroscopic changes, and histological score, but there was no significant difference between rIL-33- and PBStreated normal mice (Figure 1). These results demonstrated that rIL-33 could aggravate the symptoms of DSS-induced acute colitis in mice.

3.2. Cell Accumulation in LP of Colon Mucosa in rIL-33Treated Mice during DSS-Induced Acute Colitis. As shown in Figure 2(a), the percentage of macrophage $\left(\mathrm{CD}_{11 b^{+}} \mathrm{F} 4 /\right.$ $80^{+} \mathrm{Gr}-1^{-}$) in LPL markedly increased, but the percentage of neutrophil $\left(\mathrm{CD} 11 \mathrm{~b}^{+} \mathrm{Gr}-\mathrm{1}^{+} \mathrm{F} 4 / 80^{-}\right)$in LPL significantly decreased in colon of mice treated with rIL-33. The absolute numbers of macrophage markedly increased and the absolute numbers of neutrophil significantly decreased in mice treated with rIL-33 compared to PBS controls (Figure 2(b)). The percentage of $\mathrm{CD} 4^{+} \mathrm{CD} 44^{+}$cells in $\mathrm{CD} 4^{+} \mathrm{T}$ cells markedly increased in colon of rIL-33-treated mice as compared with those in control mice. However, the absolute numbers of $\mathrm{CD} 4^{+}$and $\mathrm{CD} 4^{+} \mathrm{CD} 44^{+}$T-LPL significantly decreased in rIL-33-treated mice when compared with those in control mice. There were no significant differences in the percent and the absolute numbers of NKT cell $\left(\mathrm{NK}^{1} 1^{+} \alpha \beta \mathrm{TCR}^{+}\right)$, $\gamma \delta \mathrm{T}$ cell $\left(\gamma \delta \mathrm{TCR}^{+} \alpha \beta \mathrm{TCR}^{-}\right)$, NK cell $\left(\mathrm{NK}_{1} 1^{+} \alpha \beta \mathrm{TCR}^{-}\right)$, $\mathrm{CD} 4^{+} \mathrm{CD} 25^{+} \mathrm{T}$ cell, and Breg cell $\left(\mathrm{B} 220^{+} \mathrm{CD} 25^{+}\right)$between DSS mice treated with rIL-33 and PBS. However, there was no 

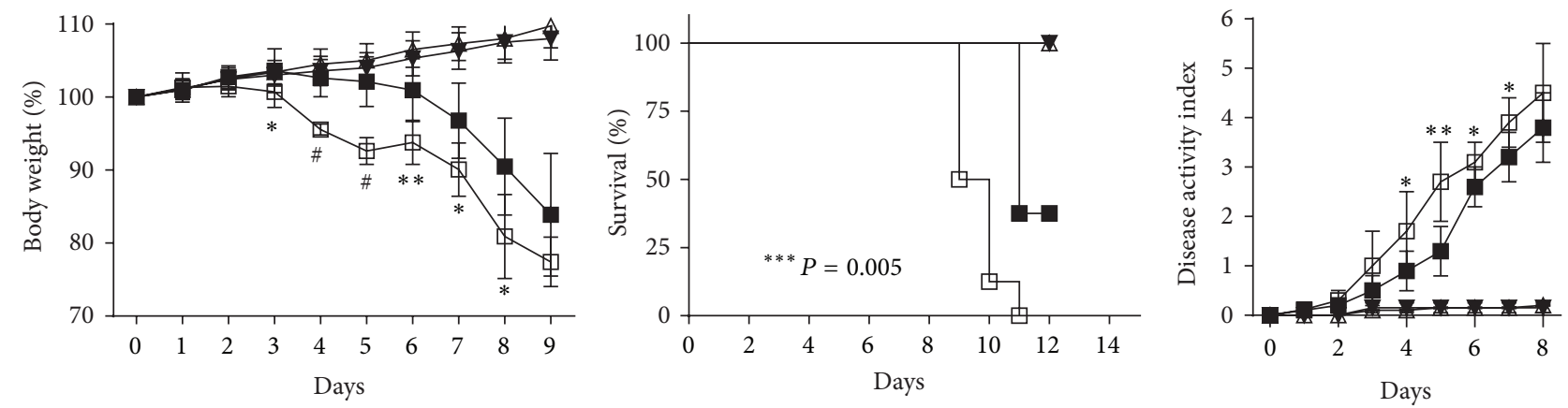

$\begin{array}{ll}\text { DSS }+ \text { PBS } & \triangle \text { PBS } \\ \square \text { DSS }+ \text { rIL-33 } & \nabla \text { rIL-33 }\end{array}$

(a)

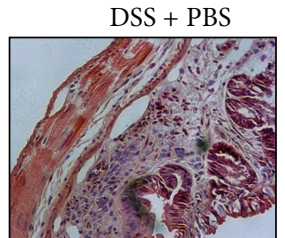

PBS

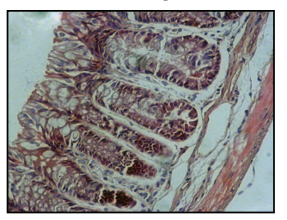

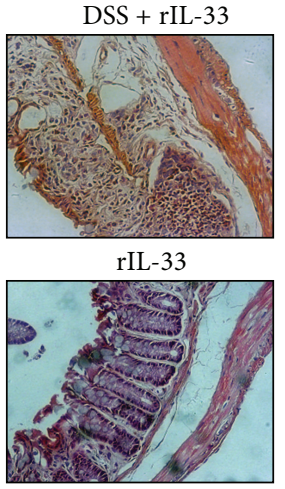

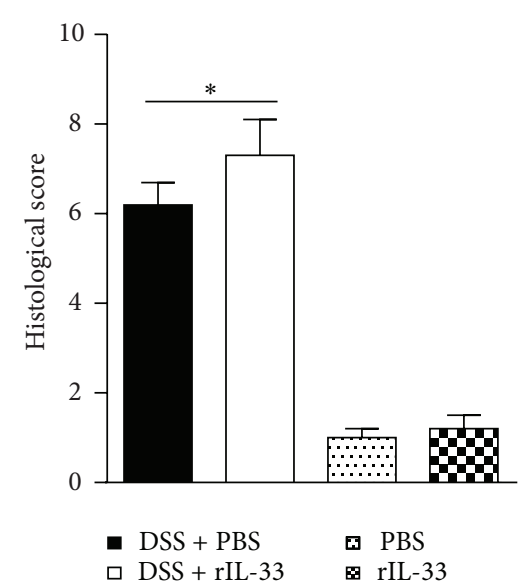

(b)
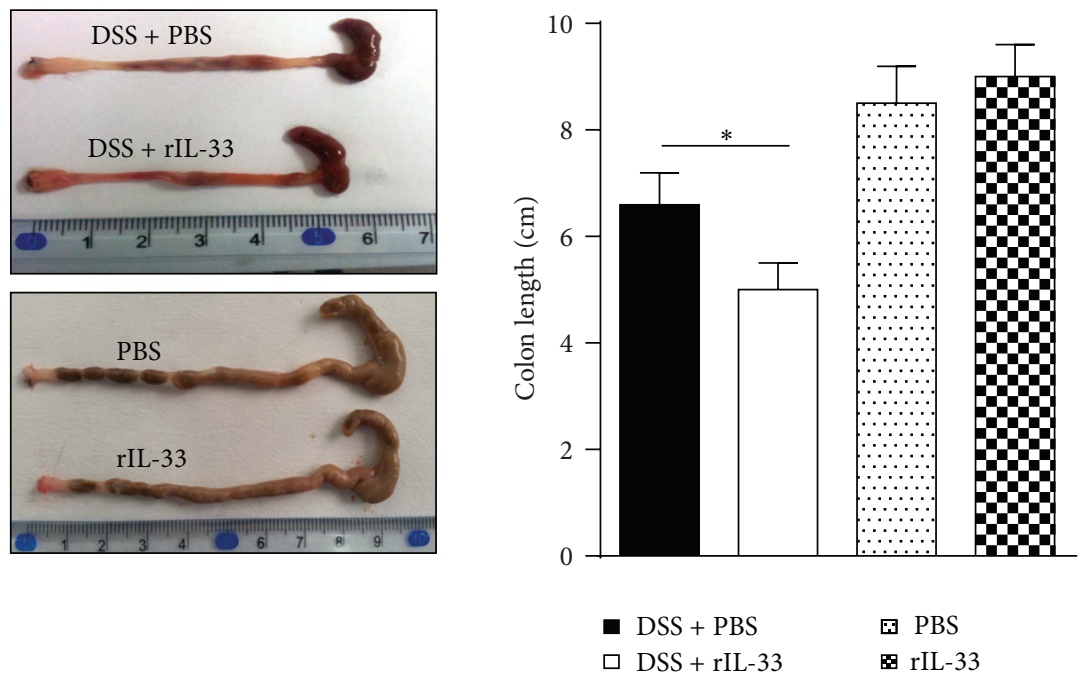

(c)

Figure 1: Administration of rIL-33 results in exacerbation of DSS-induced acute colitis. (a) Weight loss, survival rate, and disease activity index; (b) histological score (original magnification, $\times 200$ ); (c) macroscopic changes and colon length. Data indicate mean \pm SD of 8 mice of each group obtained from a representative of three independent experiments $\left(n=8\right.$ per group). ${ }^{*} P<0.05,{ }^{* *} P<0.01$, and ${ }^{\#} P<0.0001$. 
DSS + PBS
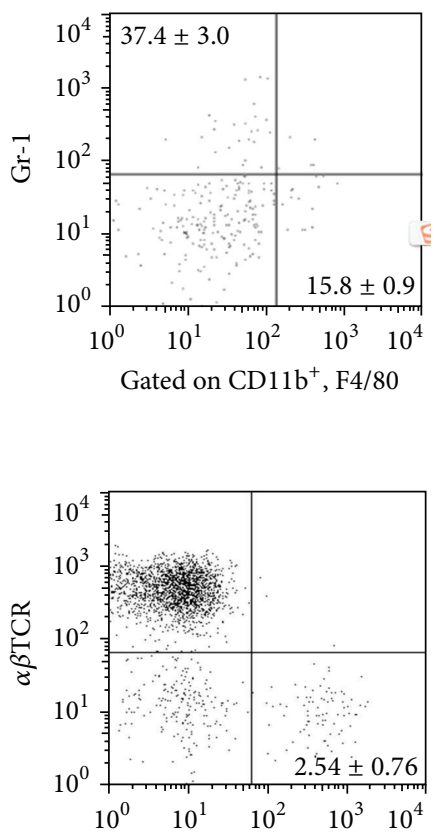

Gated on lymphocytes $\gamma \delta$ TCR

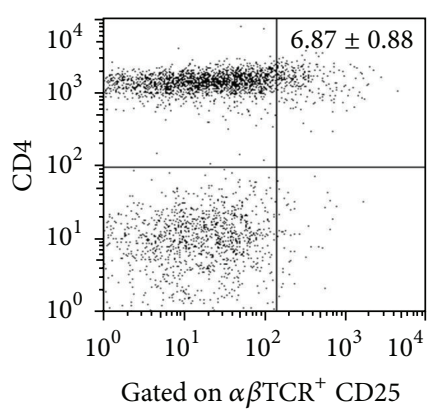

Gated on $\alpha \beta \mathrm{TCR}^{+} \mathrm{CD} 25$
DSS + rIL-33
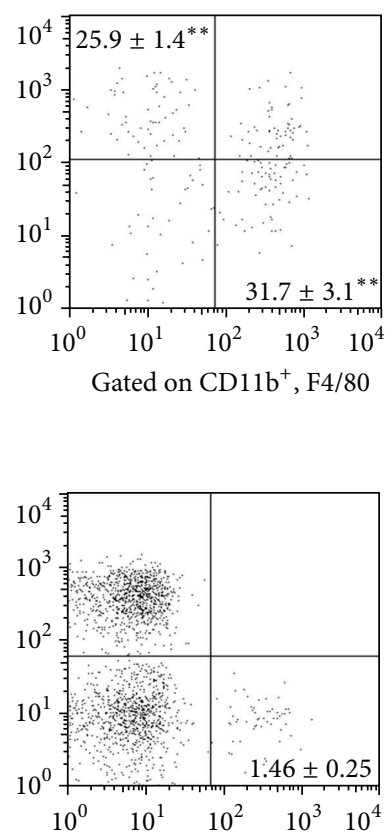

Gated on lymphocytes $\gamma \delta$ TCR
DSS + PBS
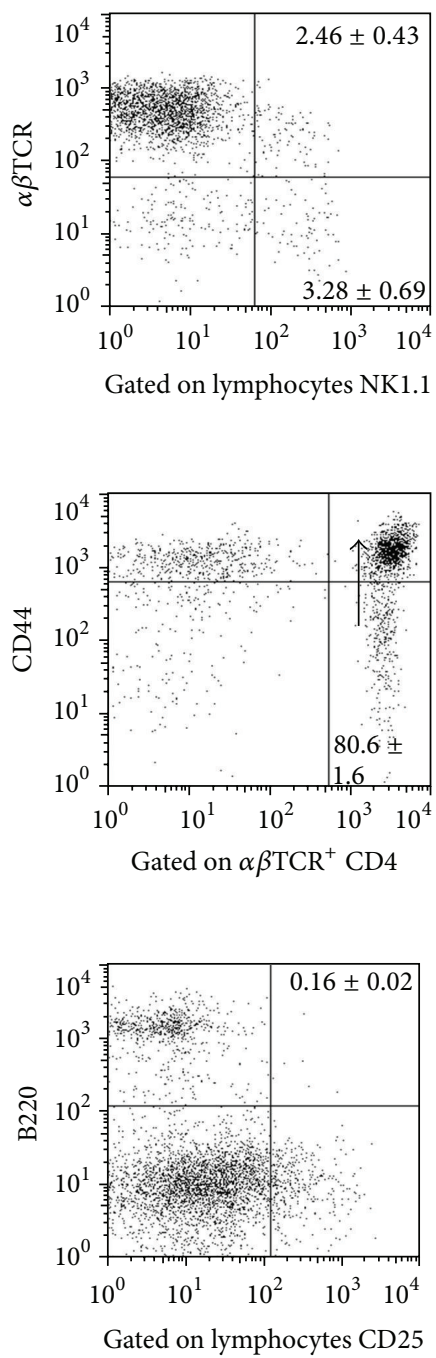

(a)
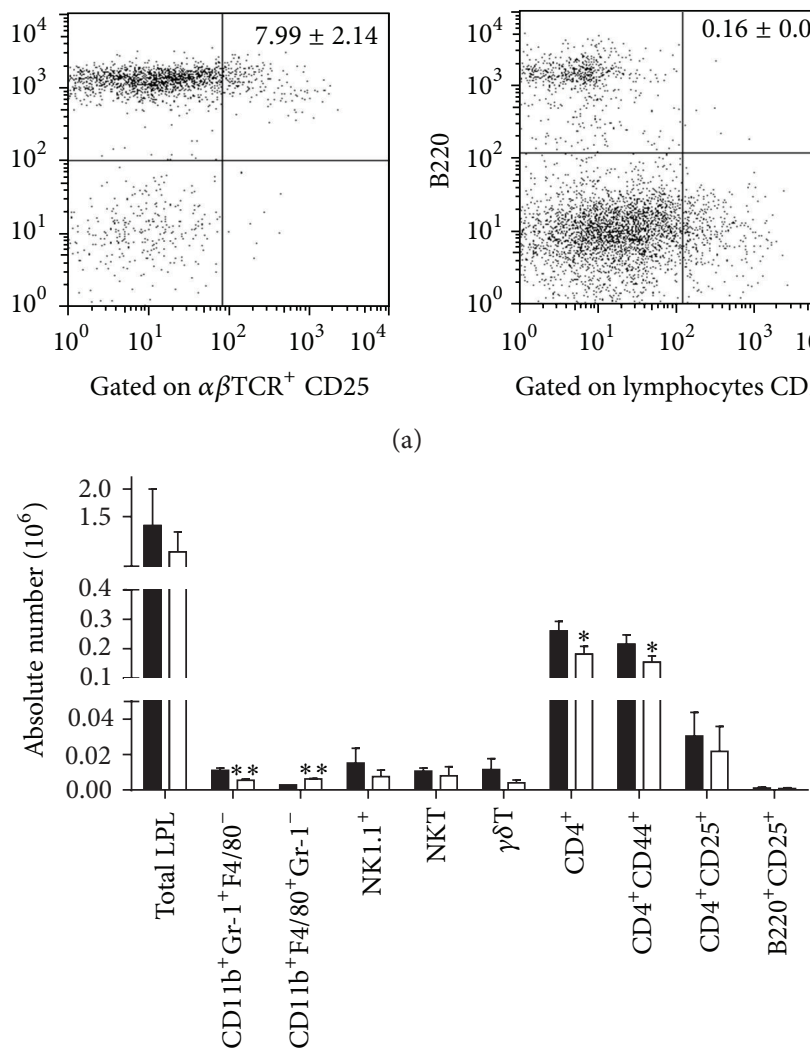

DSS + rIL-33
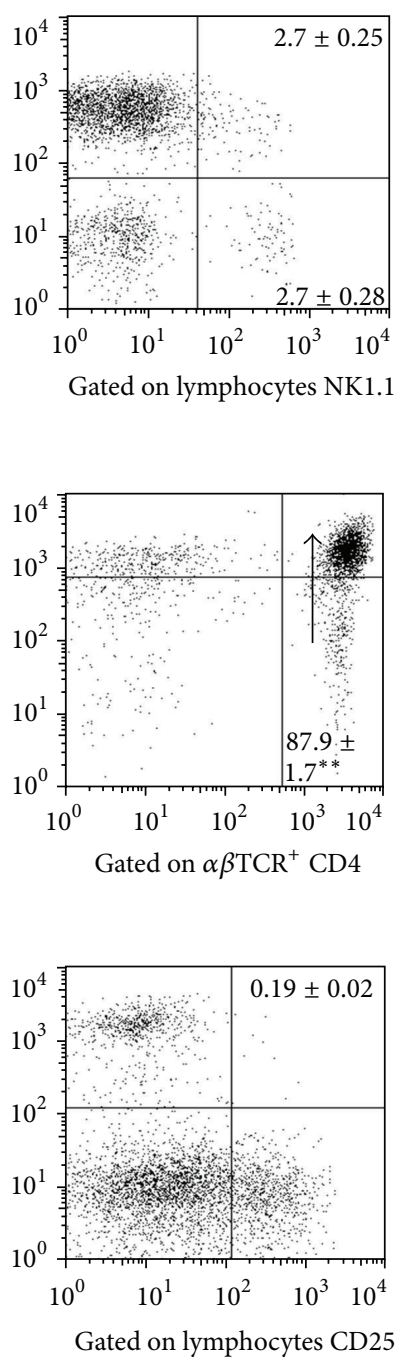

- DSS + PBS

$\square$ DSS + rIL-33

(b)

FIgure 2: Continued. 

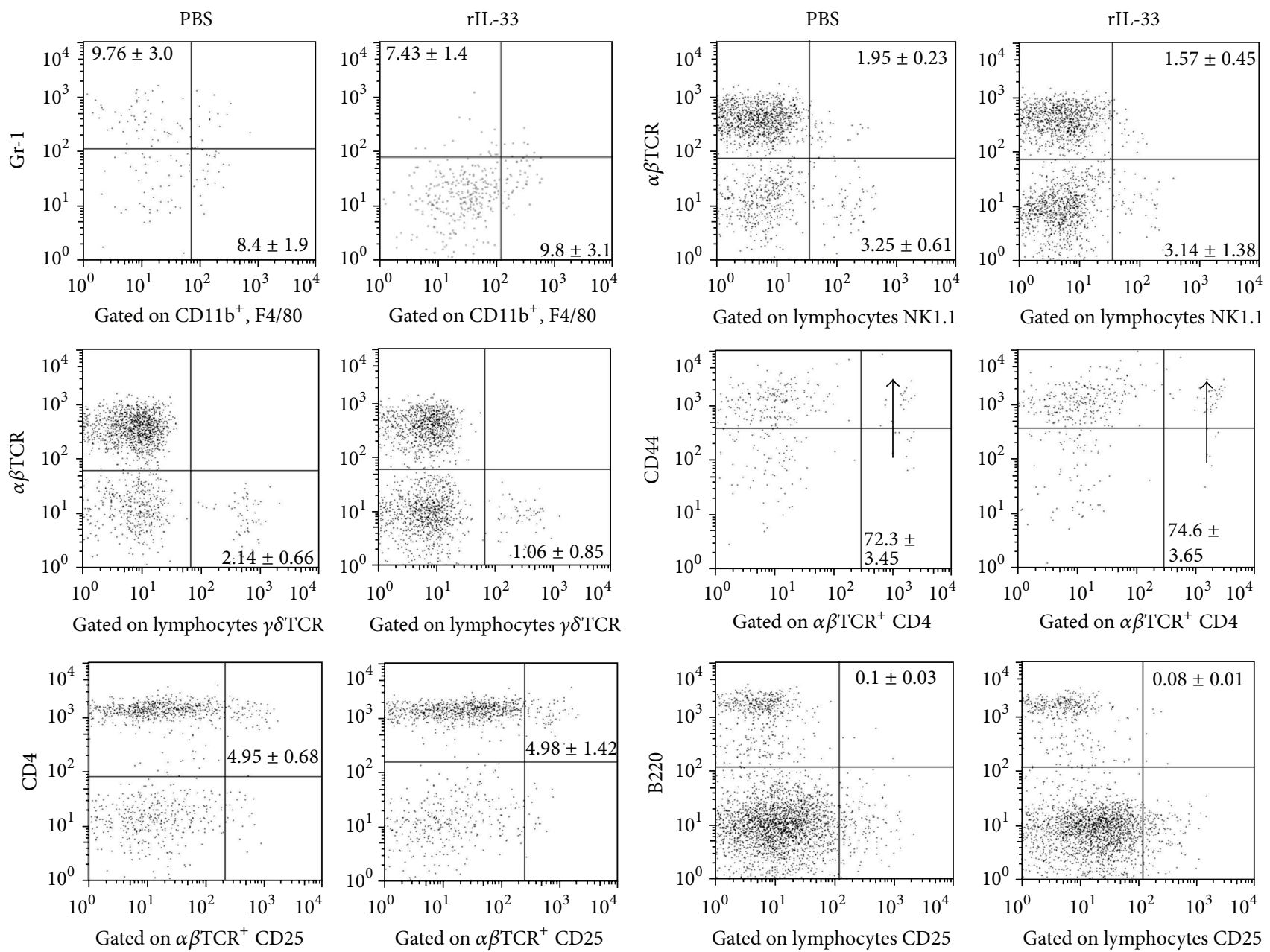

(c)

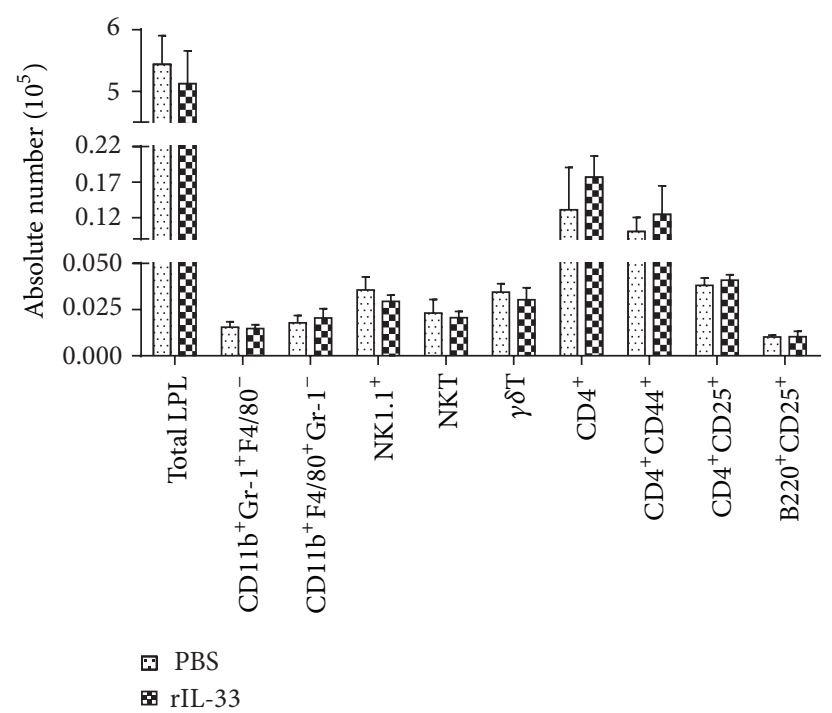

(d)

FIGURE 2: Flow cytometry analysis of the populations of LPL in the colon in rIL-33- and PBS-treated mice with or without acute colitis. ((a), (c)) The percentage of neutrophil, macrophage, $\mathrm{CD} 4^{+}, \mathrm{CD} 4^{+} \mathrm{CD} 44^{+}, \mathrm{CD} 4^{+} \mathrm{CD} 25^{+}, \mathrm{B} 220^{+} \mathrm{CD} 25^{+}, \gamma \delta \mathrm{T}$ cell, and NK and NKT cell in LP in the colon of rIL-33- and PBS-treated mice with or without acute colitis; ((b), (d)) the absolute number of LPL in the colon of rIL-33- and PBS-treated mice with or without acute colitis. Data indicating mean \pm SD obtained from a representative of three independent experiments were valued by a Student's $t$-test $\left(n=3\right.$ per group). ${ }^{*} P<0.05{ }^{* *} P<0.01$. 

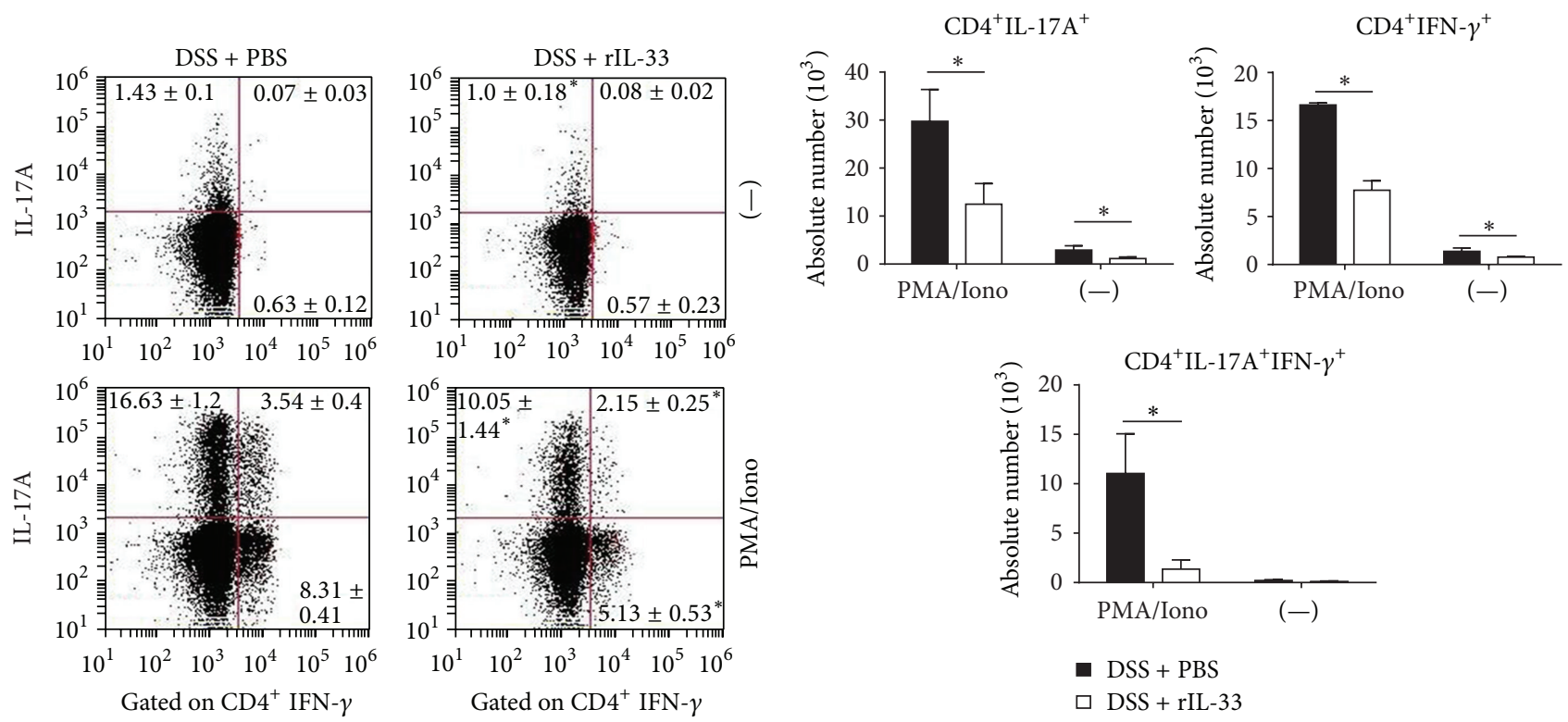

(a)
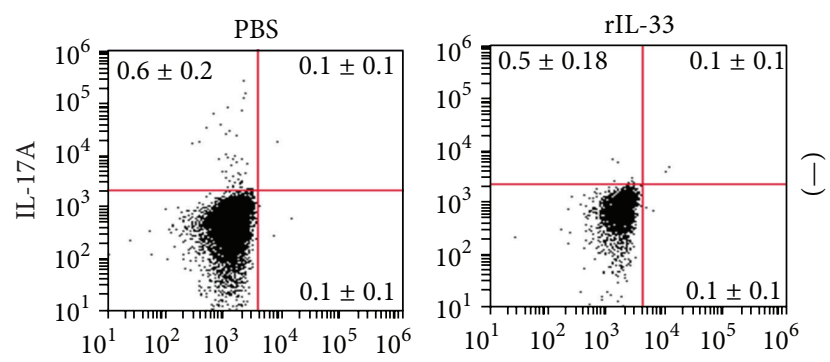

(b)
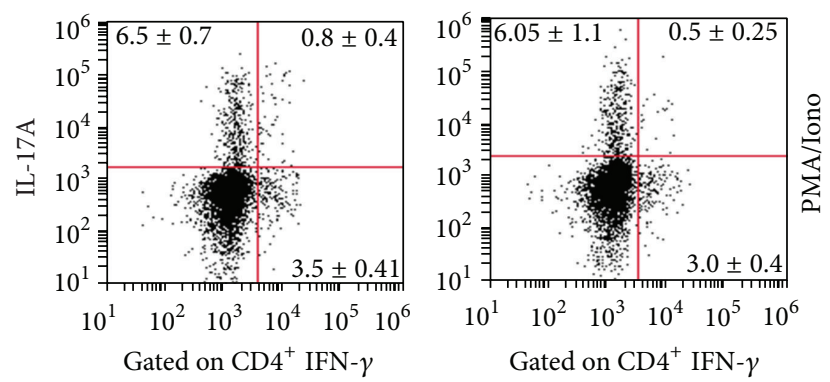

(c)
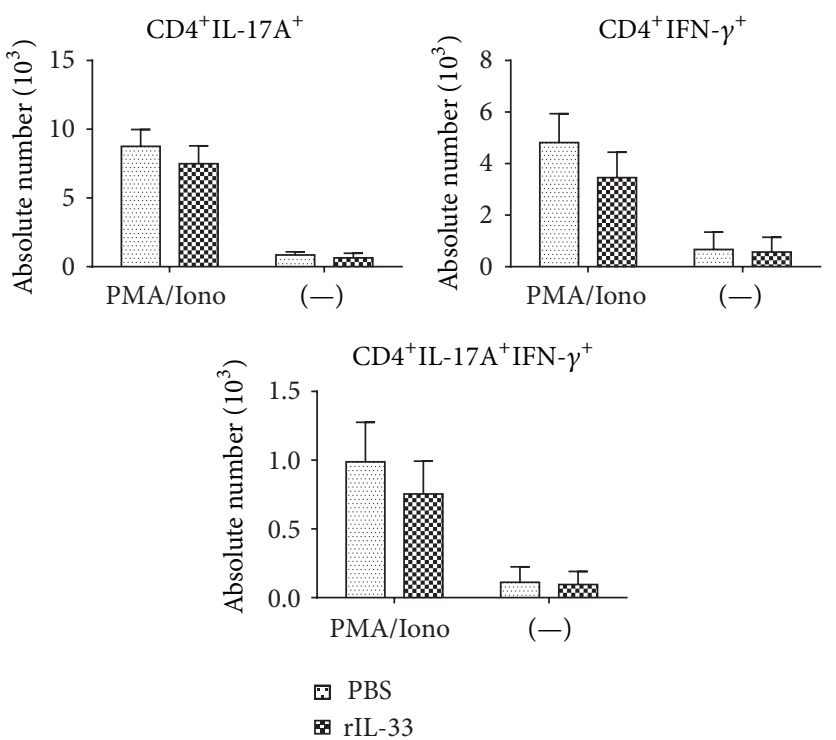

(d)

FIgURE 3: Cytokine-producing T cells in the LPL of colon in rIL-33- and PBS-treated mice with or without DSS-induced acute colitis. ((a), (c)) The percent of $\mathrm{CD} 4^{+}$IFN- $\gamma^{+}$or $\mathrm{CD} 4^{+}$IL-17A ${ }^{+}$T-LPL in the LPL of colon in rIL-33- and PBS-treated mice with or without DSS-induced acute colitis. ((b), (d)) The absolute number of $\mathrm{CD} 4^{+}$IFN- $\gamma^{+}$or $\mathrm{CD} 4^{+}$IL-17A ${ }^{+}$T-LPL in the LPL of colon in rIL-33- and PBS-treated mice with or without DSS-induced acute colitis. Data indicating mean \pm SD obtained from a representative of three independent experiments were valued by a Student's $t$-test $\left(n=4\right.$ per group). ${ }^{*} P<0.05 ;{ }^{* *} P<0.01$.

significant difference in the cell accumulation in LP of colon between PBS- and rIL-33-treated normal mice (Figures 2(c) and $2(\mathrm{~d}))$.

3.3. Cytokine Production by $C D 4^{+}$T-LPL of Colon in Mice Treated with rIL-33 during DSS-Induced Acute Colitis. We further examined the intracellular cytokine production by $\mathrm{CD}^{+}{ }^{+} \mathrm{T}$-LPL of colon in rIL-33- or PBS-treated DSS mice.
Consistent with the cell profile observed above, there was a significant reduction in the frequency of $\mathrm{CD} 4^{+} \mathrm{IL}-17 \mathrm{~A}^{+}$and $\mathrm{CD} 4^{+}$IFN- $\gamma^{+}$cells in LPL of rIL-33-treated DSS mice (Figure $3(\mathrm{a})$ ). Furthermore, we observed a reduction in the frequency of CD $4^{+}$IL-17A $^{+}$IFN- $\gamma^{+}$cells in LPL from rIL-33-treated DSS mice (Figure 3(a)) with a marked reduction in the absolute number of these cells (Figure 3(b)). However, there was a reduction but no significant difference in the frequency or the 

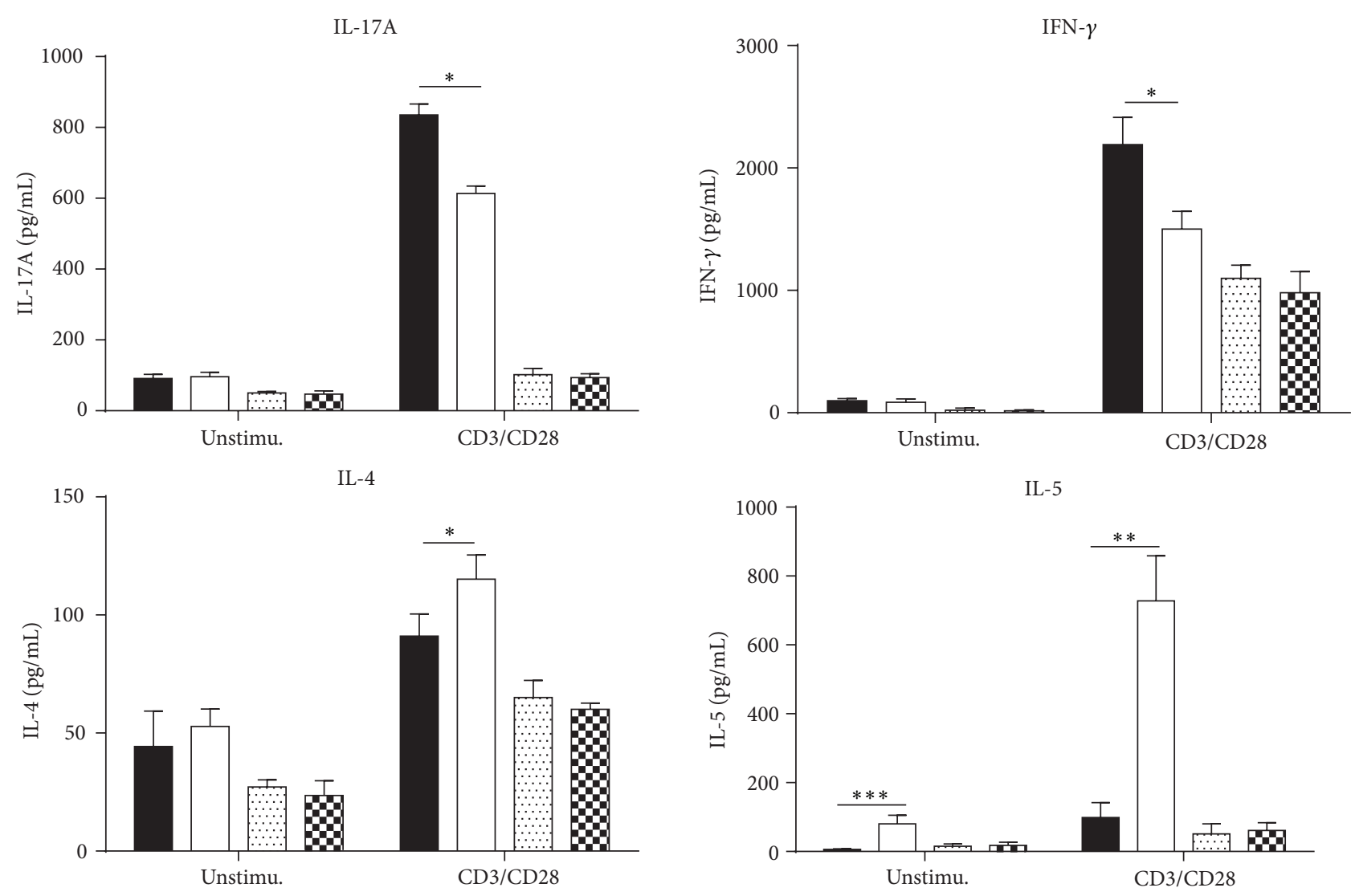

IL-10
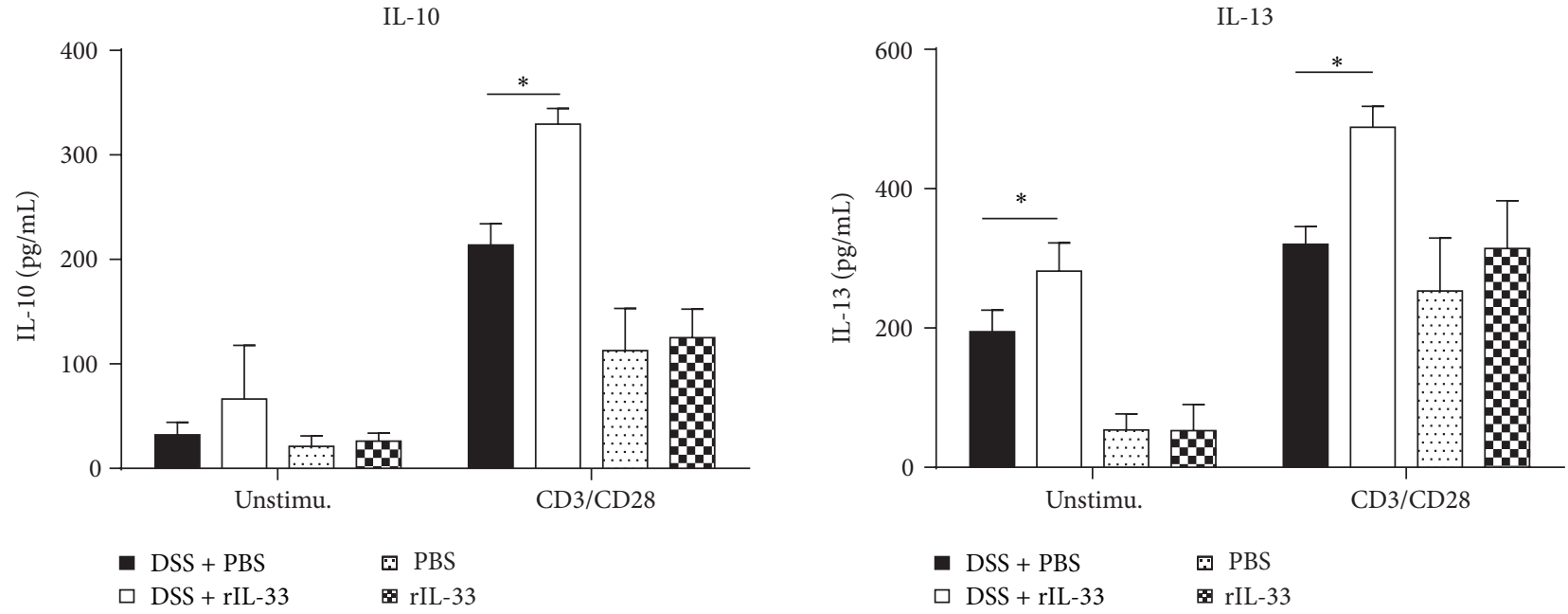

FIGURE 4: ELISA analysis of cytokine production in LP of colon in rIL-33- and PBS-treated mice with or without DSS-induced acute colitis. The level of IFN- $\gamma$, IL-17A, IL-4, IL-5, IL-13, or IL-10 production in the culture supernatants of LPL of colon was analyzed by ELISA with or without anti-CD28/anti-CD3 mAbs stimulations. Data indicating mean \pm SD obtained from a representative of three independent experiments were valued by a Student's $t$-test $\left(n=4\right.$ per group). ${ }^{*} P<0.05 ;{ }^{* *} P<0.01 ;{ }^{* * *} P<0.001$.

absolute number of $\mathrm{CD} 4^{+} \mathrm{IL}-17 \mathrm{~A}^{+}$and $\mathrm{CD} 4^{+} \mathrm{IFN}-\gamma^{+}$cells in LPL between rIL-33- and PBS-treated normal mice (Figures $3(\mathrm{c})$ and $3(\mathrm{~d}))$.

3.4. rIL-33 Shifts the Cytokine and Transcription Factors Production of DSS-Induced Acute Colitis. To explore whether
rIL-33-induced alleviation of DSS-induced acute colitis correlated with T-cell immunity, we analyzed the levels of cytokines of LPL. In the case of rIL-33-treated DSS mice, a marked reduction in the expression of IFN- $\gamma$ and IL-17A and increased production of Th2-type cytokines (IL-4, IL-5, IL10, and IL-13) were observed, compared to PBS-treated DSS 


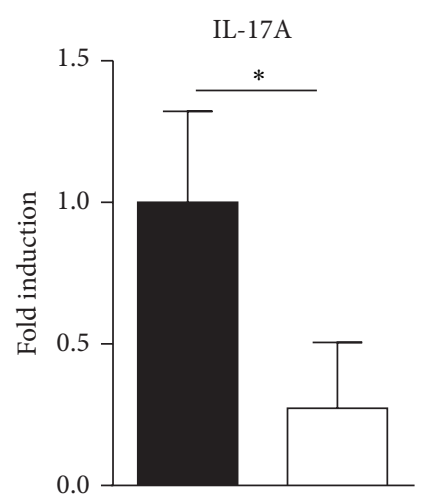

IL-10

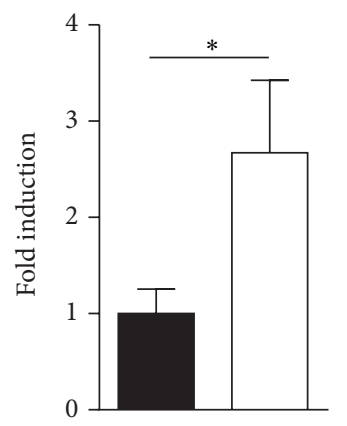

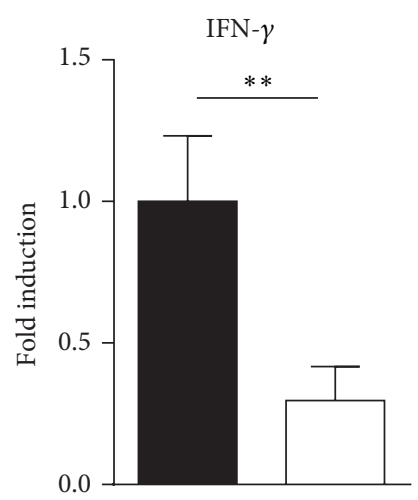

IL-13

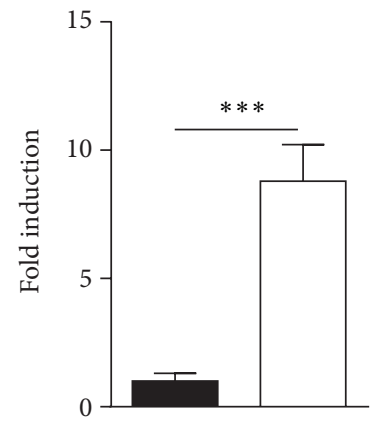

$\operatorname{ROR} \gamma \mathrm{t}$

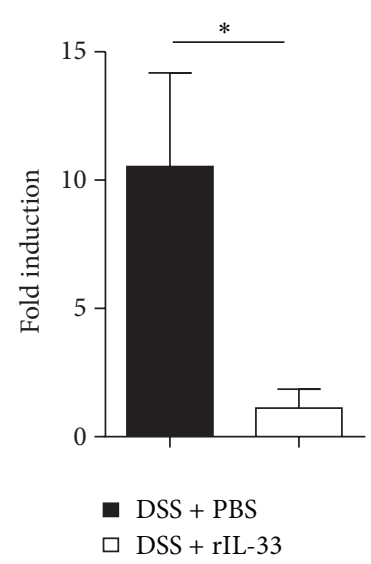

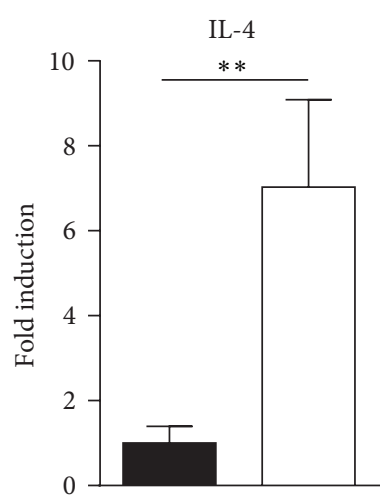

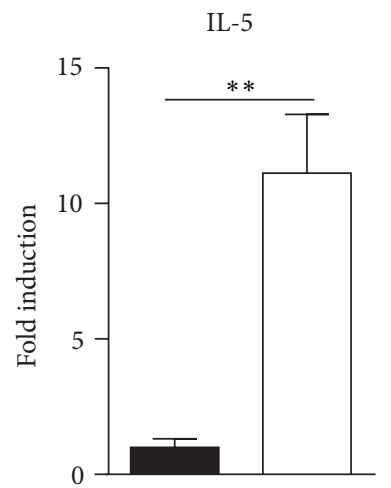

Foxp3

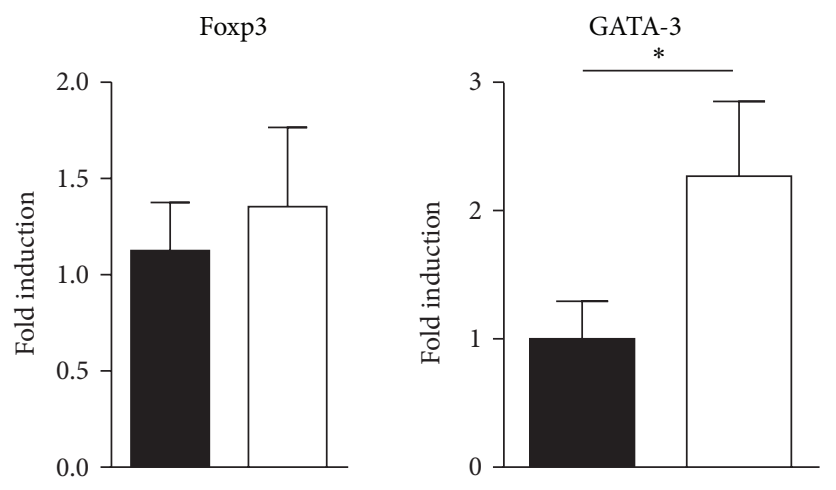

T-bet

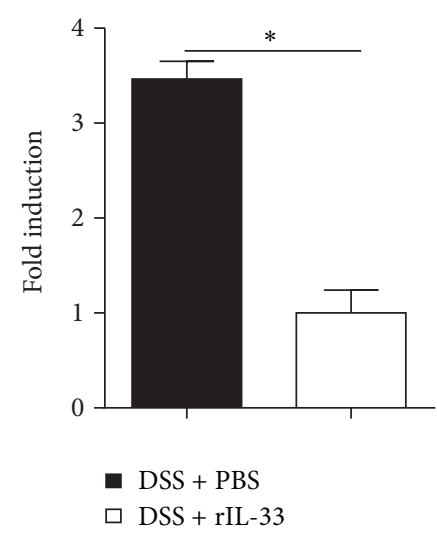

FIGURE 5: Total mRNA was extracted from colonic tissues to analyze the expression of IL-4, IL-5, IL-13, IFN- $\gamma$, IL-17A, IL-10, Foxp3, T-bet, GATA-3, and ROR $\gamma$ t by real-time PCR. Data indicating mean \pm SD obtained from a representative of three independent experiments were valued by a Student's $t$-test $\left(n=5\right.$ per group). ${ }^{*} P<0.05 ;{ }^{* *} P<0.01$; ${ }^{* * *} P<0.001$.

mice (Figure 4). Similar results were also observed by realtime PCR analysis (Figure 5). rIL-33 administration leads to a reduction in expression of T-bet and $\mathrm{ROR} \gamma \mathrm{t}$, but it leads to an increase in expression of GATA-3 (Figure 5). Other cytokines (TNF- $\alpha$, IL-1 $\beta$, IL-6, IL-23, and IL-12p70) were detected in low levels and were not significantly different between the rIL-33- and PBS-treated mice with DSS colitis (data not shown). Nonetheless, there was no significant difference in the production of IL17A, IFN- $\gamma$, IL-4, IL-5, IL-10, or IL-13 between rIL-33- and PBS-treated normal mice. These results suggested that rIL-33 treatment of mice who underwent DSSinduced acute colitis couldpromote Th2 immunity.

\section{Discussion}

In the present study, we examined the role of rIL-33 in DSSinduced acute colitis in mice. We found that rIL-33 may be involved in the development of DSS-induced acute colitis by promoting Th2 cell response in LP of the colon. Our results suggested that modulation of IL-33/ST2 signaling by $\mathrm{mAb}$ could be a novel therapy for UC.

The Th1/Th2 paradigm was used to differentiate the underlying immunological conditions of CD and UC. The dominant paradigm was that CD was characterized by a Th1 mucosal immune response, with overproduction of IFN- $\gamma$, 
while UC was thought to be characterized by a Th2 response, with excess production of IL-5 and IL-13 [34, 35]. DSSinduced acute colitis is known as a UC model, and many studies have described UC as a Th2 disease [36, 37]. Recently, Th17 has also been involved in the development of IBD $[5,6]$.

In this study, we found that rIL-33 shows the aggravating role in DSS-induced acute colitis, an inflammation model that mimics UC driven by Th2-type immune mechanisms. Furthermore, we show that the exacerbation effect of rIL-33 is accompanied by suppressing the Th1 and Th17 responses but improving Th2 reponses.

Exacerbation of DSS-induced acute colitis, characterized by Th 2 cytokine response, indicated that rIL-33 may influence processes during DSS-induced acute colitis in several ways. First, rIL-33 is capable of specifically inducing increased production of the key pathogenic Th2-type cytokines IL4 , IL-5, and IL-13. In a recent study, rIL-33 induced Th2type cytokines directly via IL-4 and IL-4R in colitis [27]. Moreover, rIL-33 can promote GATA-3 expression (Figure 5), which was consistent with a recent study in which mesenteric lymph node (MLN) T cells stimulated with rIL-33 in vitro had increased GATA-3 expression [38]. It may be another reason that rIL-33 promotes Th2 cells responses. Second, IL-33 may function as a novel epithelial "alarmin," which initiates early inflammatory immune responses [13]. This exacerbation of inflammation by rIL-33 administration could be the same as boosting the alarmin-function of endogenous IL-33, which can be released by damaged epithelial cells. IL33 can act on diverse innate immune cells (mast cells [39], eosinophils [40], basophils [41], DCs [22], macrophages [42], and neutrophils [43]) and therefore contributes to initiation of inflammation. Third, IL-33 may induce type 2 innate lymphoid cells (ILC2s) to produce IL-5 and IL-13. ILC2s, expressing significantly greater levels of ST2 and CD25 [44], need GATA-3 for their development $[45,46]$ and produced type 2 cytokines, such as IL-5 and IL-13 [47]. In our study, rIL-33 can promote IL-5 and IL-13 production without any stimulation and expression of GATA-3 (Figures 4 and 5). So, one possibility of the exacerbation of DSS-induced acute colitis by rIL-33 treatment may be that rIL-33 induced ILC2s to produce type 2 cytokines.

IFN- $\gamma$ and IL-17A are the key cytokines for Th1 and Th17 responses and are also thought to play pathogenic roles in CD and the chronic stage of DSS-induced colitis [48-50]. Recent papers reported that IL-33 attenuates EAE and experimental autoimmune uveitis by suppressing IL-17A and IFN- $\gamma$ production $[51,52]$. Similar results have also been found in our study (Figures 3-5). These results suggested that IL-33 might have a therapeutic effect in CD and the other Thl/Th17mediated immune response and mucosal inflammation.

\section{Conclusion}

The results of this study demonstrate that rIL-33 administered has an aggravated role in DSS-induced acute colitis possibly through the induction of Th2-type cytokines (IL-5 and IL-13) production together with suppression of Th1/Th17 response, and thus, by extension, modulation of IL-33/ST2 signaling by $\mathrm{mAb}$ may be a potential therapeutic reagent for human
UC. However, the exact function of IL-33 in the IBD remains unclear and merits further investigation.

\section{Conflict of Interests}

The authors declare that there is no conflict of interests regarding the publication of this paper.

\section{Acknowledgments}

This work was supported financially by the grant from the National Natural Science Foundation of China (no. 31270972) and the Doctoral Starting-Up Foundation of Liaoning (no. 201205583).

\section{References}

[1] B. Khor, A. Gardet, and R. J. Xavier, "Genetics and pathogenesis of inflammatory bowel disease," Nature, vol. 474, no. 7351, pp. 307-317, 2011.

[2] F. Scaldaferri and C. Fiocchi, "Inflammatory bowel disease: progress and current concepts of etiopathogenesis," Journal of Digestive Diseases, vol. 8, no. 4, pp. 171-178, 2007.

[3] G. M. Cobrin and M. T. Abreu, "Defects in mucosal immunity leading to Crohn's disease," Immunological Reviews, vol. 206, no. 1, pp. 277-295, 2005.

[4] S. R. Targan and L. C. Karp, "Defects in mucosal immunity leading to ulcerative colitis," Immunological Reviews, vol. 206, pp. 296-305, 2005.

[5] S. Fujino, A. Andoh, S. Bamba et al., "Increased expression of interleukin 17 in inflammatory bowel disease," Gut, vol. 52, no. 1, pp. 65-70, 2003.

[6] C. T. Weaver, L. E. Harrington, P. R. Mangan, M. Gavrieli, and K. M. Murphy, "Th17: an effector CD4 T cell lineage with regulatory T cell ties," Immunity, vol. 24, no. 6, pp. 677-688, 2006.

[7] C. O. Elson, R. B. Sartor, G. S. Tennyson, and R. H. Riddell, "Experimental models of inflammatory bowel disease," Gastroenterology, vol. 109, no. 4, pp. 1344-1367, 1995.

[8] M. Perše and A. Cerar, "Dextran sodium sulphate colitis mouse model: traps and tricks," Journal of Biomedicine and Biotechnology, vol. 2012, Article ID 718617, 13 pages, 2012.

[9] L. A. Dieleman, B. U. Ridwan, G. S. Tennyson, K. W. Beagley, R. P. Bucy, and C. O. Elson, "Dextran sulfate sodium-induced colitis occurs in severe combined immunodeficient mice," Gastroenterology, vol. 107, no. 6, pp. 1643-1652, 1994.

[10] I. Okayasu, S. Hatakeyama, M. Yamada, T. Ohkusa, Y. Inagaki, and R. Nakaya, "A novel method in the induction of reliable experimental acute and chronic ulcerative colitis in mice," Gastroenterology, vol. 98, no. 3, pp. 694-702, 1990.

[11] M. Okamura, K. Yoh, M. Ojima, N. Morito, and S. Takahashi, "Overexpression of GATA-3 in T cells accelerates dextran sulfate sodium-induced colitis," Experimental Animals, vol. 63, no. 2, pp. 133-140, 2014.

[12] J. Schmitz, A. Owyang, E. Oldham et al., "IL-33, an interleukin1-like cytokine that signals via the IL-1 receptor-related protein ST2 and induces T helper type 2-associated cytokines," Immunity, vol. 23, no. 5, pp. 479-490, 2005.

[13] C. Moussion, N. Ortega, and J.-P. Girard, "The IL-1-like cytokine IL-33 is constitutively expressed in the nucleus of endothelial cells and epithelial cells in vivo: a novel "Alarmin"?" PLOS ONE, vol. 3, no. 10, Article ID e3331, 2008. 
[14] E. S. Baekkevold, M. Roussigné, T. Yamanaka et al., "Molecular characterization of NF-HEV, a nuclear factor preferentially expressed in human high endothelial venules," The American Journal of Pathology, vol. 163, no. 1, pp. 69-79, 2003.

[15] L. Pastorelli, C. de Salvo, M. A. Cominelli, M. Vecchi, and T. T. Pizarro, "Novel cytokine signaling pathways in inflammatory bowel disease: insight into the dichotomous functions of IL-33 during chronic intestinal inflammation," Therapeutic Advances in Gastroenterology, vol. 4, no. 5, pp. 311-323, 2011.

[16] I. S. Wood, B. Wang, and P. Trayhurn, "IL-33, a recently identified interleukin-1 gene family member, is expressed in human adipocytes," Biochemical and Biophysical Research Communications, vol. 384, no. 1, pp. 105-109, 2009.

[17] M. Löhning, A. Stroehmann, A. J. Coyle et al., "T1/ST2 is preferentially expressed on murine Th2 cells, independent of interleukin 4, interleukin 5, and interleukin 10, and important for Th2 effector function," Proceedings of the National Academy of Sciences of the United States of America, vol. 95, no. 12, pp. 69306935, 1998.

[18] V. Trajkovic, M. J. Sweet, and D. Xu, “T1/ST2-an IL-1 receptorlike modulator of immune responses," Cytokine \& Growth Factor Reviews, vol. 15, no. 2-3, pp. 87-95, 2004.

[19] C. T. Fagundes, F. A. Amaral, A. L. S. Souza et al., "ST2, an IL-1R family member, attenuates inflammation and lethality after intestinal ischemia and reperfusion," Journal of Leukocyte Biology, vol. 81, no. 2, pp. 492-499, 2007.

[20] H. Hayakawa, M. Hayakawa, A. Kume, and S.-I. Tominaga, "Soluble ST2 blocks interleukin-33 signaling in allergic airway inflammation," Journal of Biological Chemistry, vol. 282, no. 36, pp. 26369-26380, 2007.

[21] M. Komai-Koma, D. Xu, Y. Li, A. N. J. McKenzie, I. B. McInnes, and F. Y. Liew, "IL-33 is a chemoattractant for human Th2 cells," European Journal of Immunology, vol. 37, no. 10, pp. 2779-2786, 2007.

[22] M. A. Rank, T. Kobayashi, H. Kozaki, K. R. Bartemes, D. L. Squillace, and H. Kita, "IL-33-activated dendritic cells induce an atypical TH2-type response," Journal of Allergy and Clinical Immunology, vol. 123, no. 5, pp. 1047-1054, 2009.

[23] J. B. Seidelin, J. T. Bjerrum, M. Coskun, B. Widjaya, B. Vainer, and O. H. Nielsen, "IL-33 is upregulated in colonocytes of ulcerative colitis," Immunology Letters, vol. 128, no. 1, pp. 80-85, 2010.

[24] A. Kobori, Y. Yagi, H. Imaeda et al., "Interleukin-33 expression is specifically enhanced in inflamed mucosa of ulcerative colitis," Journal of Gastroenterology, vol. 45, no. 10, pp. 999-1007, 2010.

[25] P. Groß, K. Doser, W. Falk, F. Obermeier, and C. Hofmann, "IL-33 attenuates development and perpetuation of chronic intestinal inflammation," Inflammatory Bowel Diseases, vol. 18, no. 10, pp. 1900-1909, 2012.

[26] M. A. K. Sedhom, M. Pichery, J. R. Murdoch et al., "Neutralisation of the interleukin-33/ST2 pathway ameliorates experimental colitis through enhancement of mucosal healing In mice," Gut, vol. 62, no. 12, pp. 1714-1723, 2013.

[27] P. N. Pushparaj, D. Li, M. Komai-Koma et al., "Interleukin-33 exacerbates acute colitis via interleukin-4 in mice," Immunology, vol. 140, no. 1, pp. 70-77, 2013.

[28] H. Imaeda, A. Andoh, T. Aomatsu et al., "Interleukin-33 suppresses Notch ligand expression and prevents goblet cell depletion in dextran sulfate sodium-induced colitis," International Journal of Molecular Medicine, vol. 28, no. 4, pp. 573-578, 2011.

[29] K. Oboki, T. Ohno, N. Kajiwara et al., "IL-33 is a crucial amplifier of innate rather than acquired immunity," Proceedings of the National Academy of Sciences of the United States of America, vol. 107, no. 43, pp. 18581-18586, 2010.

[30] L. H. Duan, J. Chen, H. W. Zhang et al., "Interleukin-33 ameliorates experimental colitis through promoting Th2/Foxp $3^{+}$ regulatory T-cell responses in mice," Molecular Medicine, vol. 18, no. 5, pp. 753-761, 2012.

[31] H. S. Cooper, S. N. S. Murthy, R. S. Shah, and D. J. Sedergran, "Clinicopathologic study of dextran sulfate sodium experimental murine colitis," Laboratory Investigation, vol. 69, no. 2, pp. 238-249, 1993.

[32] X. Sun, S. Somada, K. Shibata et al., "A critical role of CD30 ligand/CD30 in controlling inflammatory bowel diseases in mice," Gastroenterology, vol. 134, no. 2, pp. 447-458, 2008.

[33] L. A. Dieleman, M. J. H. J. Palmen, H. Akol et al., "Chronic experimental colitis induced by dextran sulphate sodium (DSS) is characterized by Th1 and Th2 cytokines," Clinical \& Experimental Immunology, vol. 114, no. 3, pp. 385-391, 1998.

[34] M. F. Neurath, S. Finotto, and L. H. Glimcher, "The role of Th1/Th2 polarization in mucosal immunit," Nature Medicine, vol. 8, no. 6, pp. 567-573, 2002.

[35] D. K. Podolsky, "Inflammatory bowel disease," The New England Journal of Medicine, vol. 347, no. 6, pp. 417-429, 2002.

[36] I. J. Fuss, F. Heller, M. Boirivant et al., "Nonclassical CD1drestricted NK T cells that produce IL-13 characterize an atypical Th2 response in ulcerative colitis," The Journal of Clinical Investigation, vol. 113, no. 10, pp. 1490-1497, 2004.

[37] F. Heller, P. Florian, C. Bojarski et al., "Interleukin-13 is the key effector Th2 cytokine in ulcerative colitis that affects epithelial tight junctions, apoptosis, and cell restitution," Gastroenterology, vol. 129, no. 2, pp. 550-564, 2005.

[38] J. B. Seidelin, M. Coskun, P. H. Kvist, T. L. Holm, K. Holgersen, and O. H. Nielsen, "IL-33 promotes GATA-3 polarization of gutderived T cells in experimental and ulcerative colitis," Journal of Gastroenterology, vol. 50, no. 2, pp. 180-190, 2015.

[39] M. Kurowska-Stolarska, P. Kewin, G. Murphy et al., "IL-33 induces antigen-specific IL- $5^{+} \mathrm{T}$ cells and promotes allergicinduced airway inflammation independent of IL-4," The Journal of Immunology, vol. 181, no. 7, pp. 4780-4790, 2008.

[40] W. B. Cherry, J. Yoon, K. R. Bartemes, K. Iijima, and H. Kita, "A novel IL-1 family cytokine, IL-33, potently activates human eosinophils," The Journal of Allergy and Clinical Immunology, vol. 121, no. 6, pp. 1484-1490, 2008.

[41] M. Suzukawa, M. Iikura, R. Koketsu et al., "An IL-1 cytokine member, IL-33, induces human basophil activation via its ST2 receptor," The Journal of Immunology, vol. 181, no. 9, pp. 59815989, 2008.

[42] M. Kurowska-Stolarska, B. Stolarski, P. Kewin et al., "IL-33 amplifies the polarization of alternatively activated macrophages that contribute to airway inflammation," The Journal of Immunology, vol. 183, no. 10, pp. 6469-6477, 2009.

[43] J. C. Alves-Filho, F. Snego, F. O. Souto et al., "Interleukin-33 attenuates sepsis by enhancing neutrophil influx to the site of infection," Nature Medicine, vol. 16, no. 6, pp. 708-712, 2010.

[44] K. R. Bartemes, K. Iijima, T. Kobayashi, G. M. Kephart, A. N. McKenzie, and H. Kita, "IL-33-responsive lineage- CD25+ CD44(hi) lymphoid cells mediate innate type 2 immunity and allergic inflammation in the lungs," The Journal of Immunology, vol. 188, no. 3, pp. 1503-1513, 2012.

[45] J. Mjösberg, J. Bernink, K. Golebski et al., "The transcription factor GATA3 is essential for the function of human Type 2 innate lymphoid cells," Immunity, vol. 37, no. 4, pp. 649-659, 2012. 
[46] T. Hoyler, C. S. N. Klose, A. Souabni et al., "The transcription factor GATA-3 controls cell fate and maintenance of type 2 innate lymphoid cells," Immunity, vol. 37, no. 4, pp. 634-648, 2012.

[47] D. R. Neill, S. H. Wong, A. Bellosi et al., "Nuocytes represent a new innate effector leukocyte that mediates type-2 immunity," Nature, vol. 464, no. 7293, pp. 1367-1370, 2010.

[48] F. Obermeier, G. Kojouharoff, W. Hans, J. Schölmerich, V. Gross, and W. Falk, "Interferon-gamma (IFN- $\gamma$ )- and tumour necrosis factor (TNF)-induced nitric oxide as toxic effector molecule in chronic dextran sulphate sodium (DSS)-induced colitis in mice," Clinical and Experimental Immunology, vol. 116, no. 2, pp. 238-245, 1999.

[49] M. Leppkes, C. Becker, I. I. Ivanov et al., "ROR $\gamma$-expressing Th17 cells induce murine chronic intestinal inflammation via redundant effects of IL-17A and IL-17F," Gastroenterology, vol. 136, no. 1, pp. 257-267, 2009.

[50] F. Sanchez-Muñoz, A. Dominguez-Lopez, and J. K. YamamotoFurusho, "Role of cytokines in inflammatory bowel disease," World Journal of Gastroenterology, vol. 14, no. 27, pp. 4280-4288, 2008.

[51] H.-R. Jiang, M. Milovanović, D. Allan et al., "IL-33 attenuates EAE by suppressing IL-17 and IFN- $\gamma$ production and inducing alternatively activated macrophages," European Journal of Immunology, vol. 42, no. 7, pp. 1804-1814, 2012.

[52] M. Barbour, D. Allan, H. Xu et al., "IL-33 attenuates the development of experimental autoimmune uveitis," European Journal of Immunology, vol. 44, no. 11, pp. 3320-3329, 2014. 


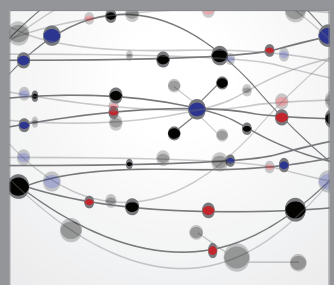

The Scientific World Journal
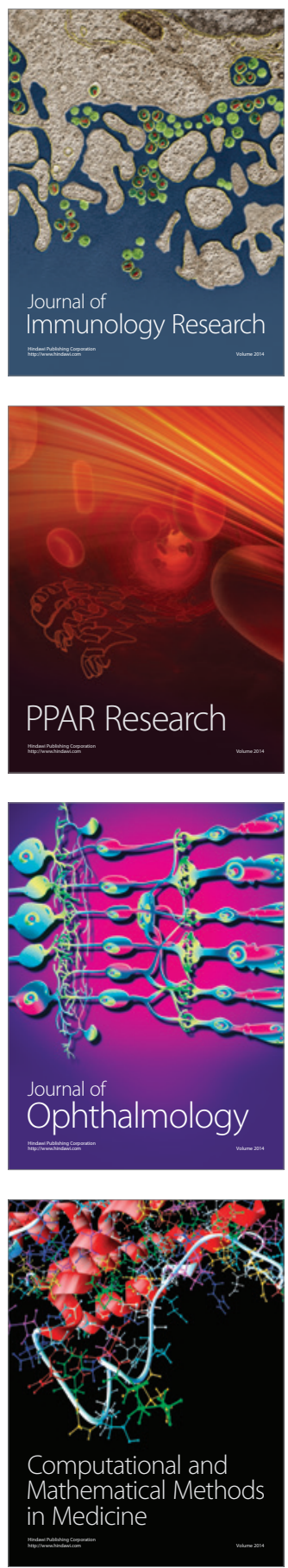

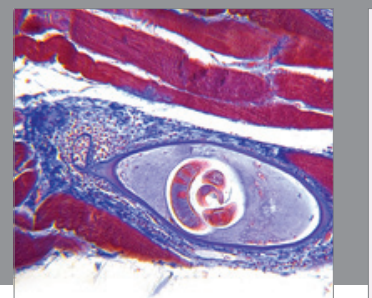

Gastroenterology

Research and Practice
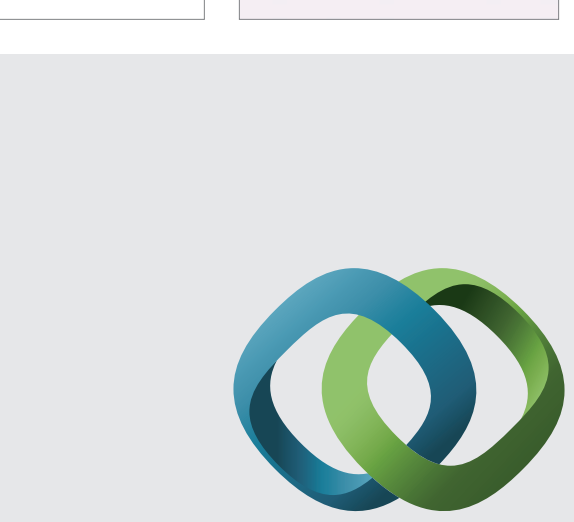

\section{Hindawi}

Submit your manuscripts at

http://www.hindawi.com
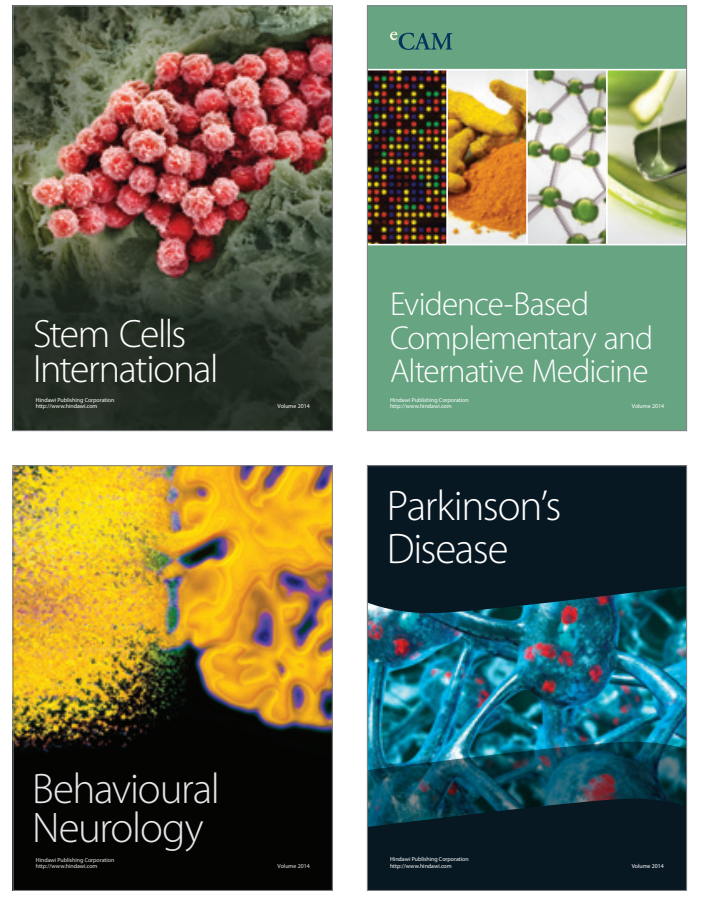
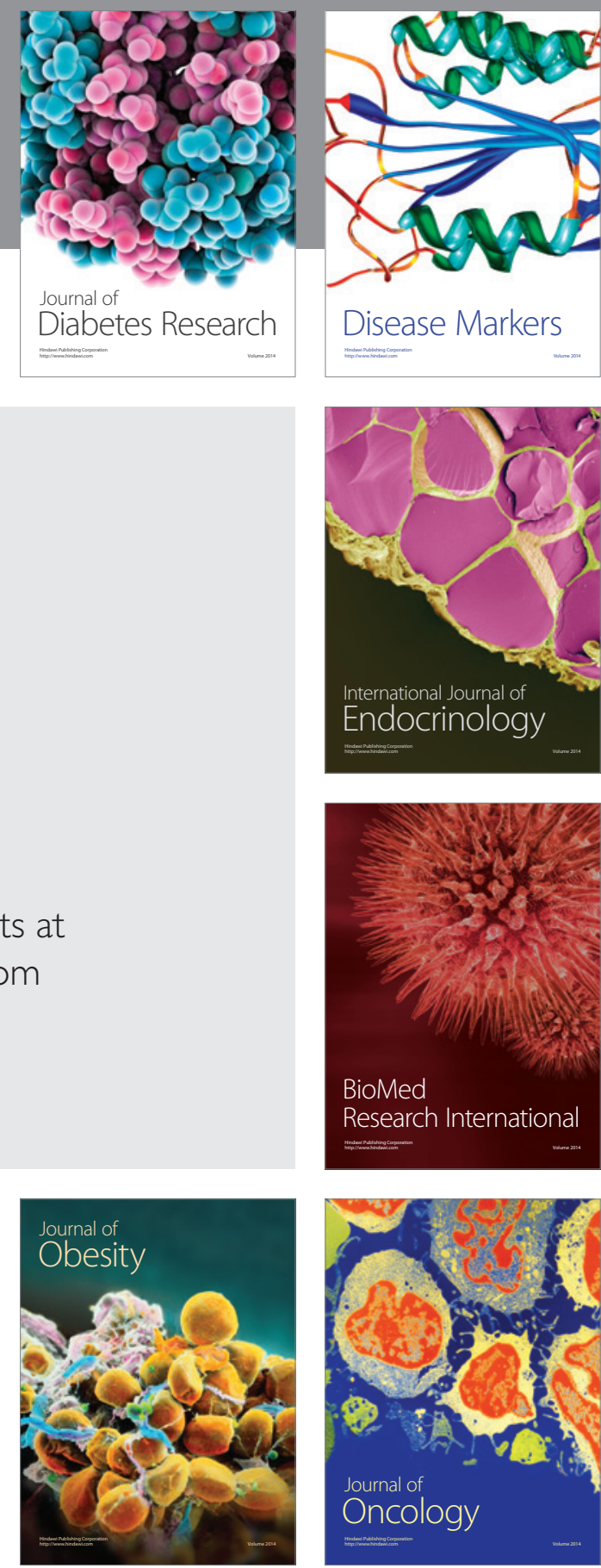

Disease Markers
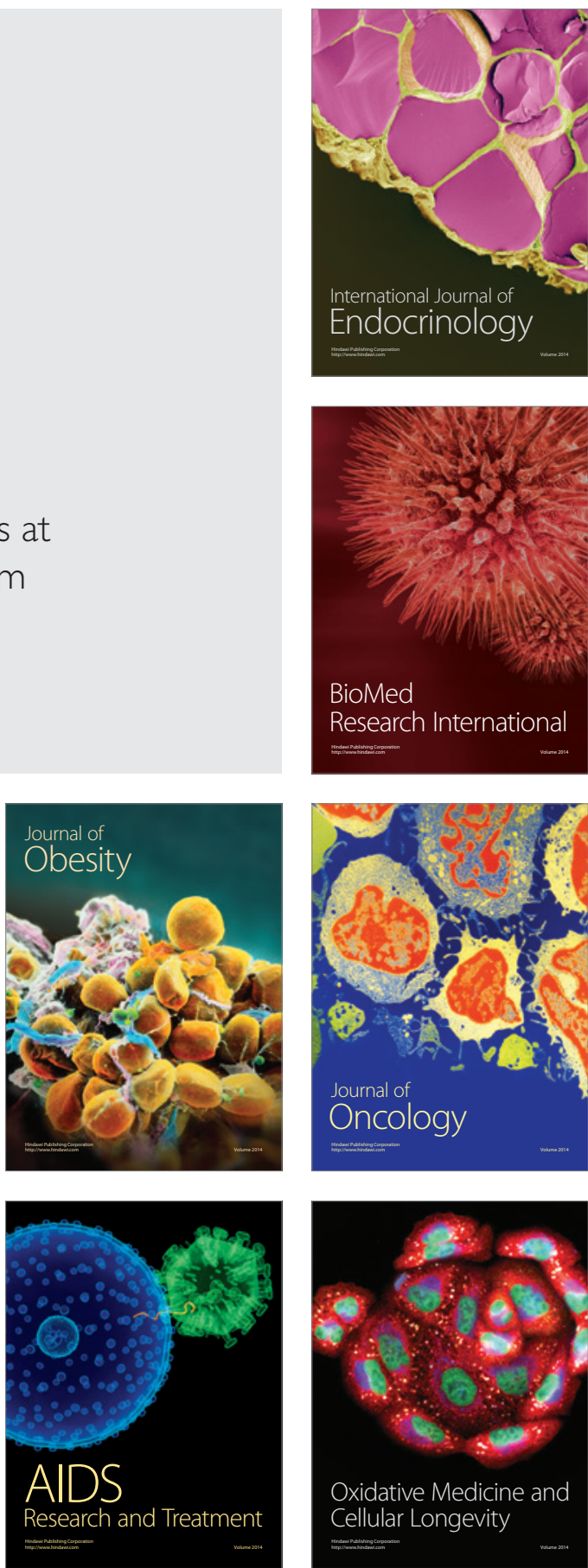